THE EFFECT OF OPERATIONAL COST PER OPERATIONAL INCOME (BOPO), NON PERFORMING LOAN (NPL) AND LOAN TO DEPOSIT RATIO (LDR) ON RETURN ON ASSET (ROA) (Case Study at PT Bank Pembangunan Daerah Nusa Tenggara Timur)

\title{
PENGARUH BIAYA OPERASIONAL PER PENDAPATAN OPERASIONAL (BOPO), NON PERFORMING LOAN (NPL) DAN LOAN TO DEPOSIT RATIO (LDR) TERHADAP RETURN ON ASSET (ROA) (Studi Kasus Pada PT Bank Pembangunan Daerah Nusa Tenggara Timur)
}

\author{
${ }^{1}$ Maximus L. Taolin \\ ${ }^{1}$ maxtaolin@yahoo.com \\ ${ }^{2}$ Aquidowaris Manek \\ 2arismanek807@gmail.com \\ ${ }^{3}$ Adriana Enggelina Nokas \\ ${ }^{1,2,3}$ Fakultas Ekonomi dan Bisnis, Universitas Timor
}

\begin{abstract}
This study aims to determine the effect of Operational Costs per Operating Income (BOPO), Non Performing Loans (NPL) and Loan to Deposit Ratio (LDR) on Return On Assets (ROA) (Case Study at PT Bank Pembangunan Daerah Nusa Tenggara Timur)". Data collection techniques used are documentation and observation. The population in this study was PT Bank Pembangunan Daerah Nusa Tenggara Timur, and the sample studied was 49 respondents (49 quarters of the research variables) with the sampling technique used was purposive sampling. The data analysis techniques used are: descriptive and inferential with simple linear regression analysis tools and multiple linear regression. The results of the study show that partially the BOPO (X1) and NPL (X2) variables have a negative and significant effect on ROA of Bank NTT; while LDR (X3) has no significant effect on Bank NTT's ROA. Simultaneously, the BOPO, NPL, and LDR variables affect the ROA of NTT Bank.
\end{abstract}

Keywords: ROA, BOPO, NPL, and LDR

\begin{abstract}
Abstrak
Penelitian ini bertujuan untuk mengetahui Pengaruh Biaya Operasional per Pendapatan Operasional (BOPO), Non Performing Loan (NPL) dan Loan to Deposit Ratio (LDR) terhadap Return On Asset (ROA) (Studi Kasus Pada PT Bank Pembangunan Daerah Nusa Tenggara Timur)". Teknik pengumpulan data yang digunakan adalah dokumentasi dan observasi. Populasi dalam penelitian ini adalah PT Bank Pembangunan Daerah Nusa Tenggara Timur, dan sampel yang diteliti sebanyak 49 responden (49 triwulan dari variabel-variabel penelitian) dengan teknik sampling yang digunakan adalah purposive sampling. Teknik analisis data yang digunakan adalah : deskriptif dan inferensial dengan alat analisis regresi linear sederhana dan regresi linear berganda. Hasil pada penelitian menunjukkan bahwa secara parsial variabel BOPO (X1) dan NPL (X2) berpengaruh negatif dan signifikan terhadap ROA Bank NTT; sedangkan LDR (X3) tidak berpengaruh signifikan terhadap ROA Bank NTT. Secara simultan variabel BOPO, NPL, dan LDR berpengaruh terhadap ROA Bank NTT.
\end{abstract}

Kata kunci : ROA, BOPO, NPL, dan LDR

\section{PENDAHULUAN}

Bank merupakan sebuah badan usaha dengan fungsi sebagai perantara keuangan antara pihak yang kelebihan dana dan pihak yang kekurangan dana. Tujuan utama bank adalah mendapatkan keuntungan (profit) dan meningkatkan kekayaan para pemegang sahamnya dengan harapan dapat menunjang kelangsungan hidup suatu bank. Bank Pembangunan Daerah (BPD) yang merupakan bagian dari industri perbankan nasional juga 
harus menunjukkan kinerja efisiensi yang optimal dalam rangka mendukung sepenuhnya pembiayaan pembangunan daerah.

Analisis laporan keuangan adalah salah satu alat yang dapat digunakan untuk menilai kinerja perusahaan apakah perusahaan dalam kondisi yang baik atau tidak. Dengan analisis rasio keuangan akan dapat diketahui seperti apa kondisi kinerja keuangan perusahaan (Tanor, Sabijono, \& Walandouw, 2015:640). Kinerja bank yang baik umumnya dapat diketahui melalui berbagai macam variabel atau indikator. Menurut Syofyan (dalam Maria (2015:3), profitabilitas merupakan indikator yang tepat untuk mengukur kinerja suatu bank. Ukuran profitabilitas yang digunakan adalah Return on Asset (ROA). Selain rasio return on asset (ROA) ada beberapa rasio yang berpengaruh terhadap kinerja perbankan seperti BOPO, NPL dan LDR.

\section{Return on Asset (ROA)}

Menurut Bank Indonesia, ROA adalah rasio yang mengukur tingkat keuntungan atau laba yang menunjukan tingkat efisiensi harta dari lembaga keuangan bank. Formula Return On Asset (ROA) dalam surat edaran Bank Indonesia No. 13/24/DPDN/2011 untuk semua bank umum konvensional yaitu:

$R O A=\frac{\text { Laba Sebelum Pajak }}{\text { Rata-rata Total Aset }}$

\section{Biaya Operasional Per Pendapatan Operasional (BOPO)}

Biaya operasional per pendapatan operasional atau biasa disingkat BOPO merupakan rasio efisiensi bank yang mengukur beban operasional terhadap pendapatan operasional. Rasio BOPO ini bertujuan untuk mengukur kemampuan pendapatan operasional dalam menutup biaya operasional. Formula untuk menghitung nilai BOPO dalam surat edaran Bank Indonesia No. 13/1/PBI/2011 untuk semua bank umum konvensional yaitu:

\section{$B O P O=\frac{\text { Total Biaya Operasional }}{\text { Total Pendapatan Operasional }}$}

Nilai ROA bank sangat dipengaruhi oleh besar kecilnya BOPO. Semakin besar BOPO akan berpengaruh buruk dengan menurunnya ROA bank. Hasil penelitian dari Putra (2013), Dewi, Herawati, \& Sulindawati (2015), Dewi A. S (2017), Fajari \& Sunarto (2017), Maria (2015), Peling \& Sedana (2018), Wibisono \& Wahyuni (2017) dan Yolanda ( 2019) menyatakan bahwa variabel BOPO berpengaruh negatif dan signifikan terhadap ROA bank.

$H_{1}$ : Biaya Operasional Per Pendapatan Operasional $\left(X_{1}\right)$, berpengaruh negatif dan signifikan terhadap Return On Asset (Y) PT Bank Pembangunan Daerah Nusa Tenggara Timur.

\section{Non Performing Loan (NPL)}

Kasmir (2015) dalam Halimah \& Komariah (2017:15) mengatakan NPL merupakan rasio yang dipergunakan untuk mengukur kemampuan bank dalam meng-cover risiko kegagalan pengembalian kredit oleh debitur. Dalam peraturan Bank Indonesia nomor 6/10/PBI/2004 tanggal 12 April 2004 tentang penilaian tingkat kesehatan bank umum, bank harus menjaga NPL dibawah 5\% tetapi jika NPL diatas 5\% dan lebih maka bank tersebut tidak sehat. Dalam surat edaran Bank Indonesia No. 13/1/PBI/2011, sistematis atau formula NPL yaitu:

\section{$N P L=\frac{\text { Total Kredit Bermasalah }}{\text { Total Kredit }}$}

Besar kecilnya nilai NPL akan mempengaruhi tingkat rentabilitas dalam hal ini Return On Asset (ROA) PT Bank NTT. Jika nilai NPL semakin besar maka dapat mengurangi nilai dari ROA. Hal ini berarti adanya hubungan yang negatif antara variabel NPL terhadap ROA bank. Penelitian yang dilakukan oleh Dewi, Herawati, \& Sulindawati (2015), Dewi A. S 
(2017) dan Peling \& Sedana (2018) menyatakan bahwa variabel NPL berpengaruh negatif dan signifikan terhadap ROA bank.

\section{$\mathrm{H}_{2}$ : Non Performing Loan $\left(\mathrm{X}_{2}\right)$ berpengaruh negatif dan signifikan terhadap Return On Asset (Y) PT Bank Pembangunan Daerah Nusa Tenggara Timur.}

\section{Loan to Deposit Ratio (LDR)}

LDR merupakan ratio yang menunjukkan tingkat likuiditas suatu bank. Juga menunjukkan kemampuan dalam menjalankan fungsi intermediasinya dalam menyalurkan dana pihak ketiga ke kredit. Ketentuan LDR menurut Bank Indonesia adalah maksimum 110\%. Eddie, (dalam Sohilauw, 2016:8). Formula untuk menghitung nilai LDR dalam surat edaran Bank Indonesia No.13/24/DPNP/2011 untuk semua bank umum konvensional yaitu:

\section{$L D R=\frac{\text { Total Kredit }}{\text { Dana Pihak Ketiga }}$}

Semakin tinggi nilai rasio LDR menunjukkan semakin rendahnya kemampuan likuiditas bank yang bersangkutan sehingga kemungkinan suatu bank dalam kondisi bermasalah akan semakin besar. Adyani, (dalam Pratiwi \& Wiagustini, 2015:2148), sebaliknya semakin rendah rasio LDR menunjukkan kurangnya efektifitas bank dalam menyalurkan kredit sehingga hilangnya kesempatan bank untuk memperoleh laba. Jika rasio berada pada standar yang ditetapkan bank Indonesia, maka laba akan meningkat (dengan asumsi bank tersebut menyalurkan kreditnya dengan efektif). Meningkatnya laba, maka Return On Asset (ROA) juga akan meningkat, karena laba merupakan komponen yang membentuk ROA (Pratiwi \& Wiagustini, 2015:2148). Hasil penelitian dari Dewi, Herawati, \& Sulindawati ( 2015), Peling \& Sedana (2018) dan Putra (2013) menyatakan bahwa variabel NPL berpengaruh positif dan signifikan terhadap ROA bank.

\section{$\mathrm{H}_{3}$ : Loan To Deposit Ratio $\left(\mathrm{X}_{3}\right)$ berpengaruh positif dan signifikan terhadap Return On Asset (ROA)(Y) PT Bank Pembangunan Daerah Nusa Tenggara Timur.}

Menurut Bank Indonesia, efisiensi operasi diukur dengan membandingkan total biaya operasi dengan total pendapatan operasi atau yang sering disebut BOPO. Fluktuasinya nilai BOPO akan mempengaruhi nilai dari ROA. Apabila nilai BOPO menurun berarti pendapatan operasional lebih besar dari biaya operasional, maka ROA Bank NTT akan meningkat dan sebaliknya. NPL mencerminkan kesulitan pelunasan pinjaman yang telah jatuh tempo oleh debitur. NPL ini mengukur tingkat kualitas kredit yang membandingkan antara toal kredit bermasalah terhadap total kredit yang dikeluarkan oleh bank kepada para debitur. Semakin besar tingkat NPL menunjukan tingkat kerugian yang semakin besar, sebab bank akan mengalokasikan tambahan dana untuk menutupi besarnya kredit yang bermasalah atau adanya penambahan dana pada akun Penyisihan Penghapusan Aktiva Produktif (PPAP).

Kinerja likuiditas digunakan untuk mengukur kemampuan suatu bank dalam membayar kewajiban - kewajiban jangka pendeknya seperti tabungan, deposito dan giro. Kinerja likuiditas dapat diukur dengan Loan to Deposit Ratio (LDR), rasio ini digunakan untuk menunjukkan kemampuan bank dalam menarik dana simpanan masyarakat atau dana pihak ketiga dengan dana yang dikeluarkan dalam bentuk kredit. LDR memiliki pengaruh terhadap ROA, hal ini disebabkan apabila LDR meningkat berarti terjadi peningkatan total kredit dengan persentase lebih besar dari persentase peningkatan total dana pihak ketiga, akibatnya pendapatan yang diterima bank lebih besar dari biaya yang dikeluarkan, sehingga laba meningkat dan ROA juga meningkat.

Dari uraian diatas, jawaban sementara atau hipotesis dari pengaruh secara simultan variabel indepeden terhadap variabel dependen, sebagai berikut: 


\section{$\mathrm{H}_{4}$ : Variabel BOPO, NPL dan LDR berpengaruh terhadap variabel Return On Asset (ROA) PT Bank Pembangunan Daerah Nusa Tenggara Timur.}

\section{METODE}

Penelitian ini dilakukan pada PT Bank Pembangunan Daerah Nusa Tenggara Timur. Untuk periode kinerja PT Bank Pembangunan Daerah Nusa Tenggara Timur yang diteliti yaitu dari tahun 2011-2020 (Triwulan). Populasi dalam penelitian ini adalah PT Bank Pembangunan Daerah Nusa Tenggara Timur. Sampel dari penelitian ini adalah data time series (Triwulan) dari tahun 2011-2020 variabel-variabel yang diteliti, antara lain data Return On Asset (ROA), Biaya Operasional Per Pendapatan Operasional (BOPO), Non Performing Loan (NPL) dan Loan To Deposit Ratio (LDR) dari PT Bank Pembangunan Daerah Nusa Tenggara Timur. Sumber data yang digunakan adalah data sekunder. Sumber data dalam penelitian ini ialah data time series (40 triwulan) selama 10 tahun dari publikasi laporan keuangan PT Bank Pembangunan Daerah Nusa Tenggara Timur, publikasi dari Otoritas Jasa Keuangan (OJK) Indonesia serta buku-buku lainya yang dapat dijadikan tambahan informasi. Teknik analisis data yang digunakan adalah analisis deskriptif dan analisis inferensial.

\section{PEMBAHASAN}

\section{Uji Normalitas}

\section{Normal P-P Plot Regression Residual}

Normal P-P Plot Regression Residual. Jika nilai residual menyebar secara teratur mengikuti sumbu diagonal dari titik nol, maka dapat disimpulkan bahwa data peneltian telah terdistribusi secara normal.

Grafik 1. Normal P-P Plot Regression Residual

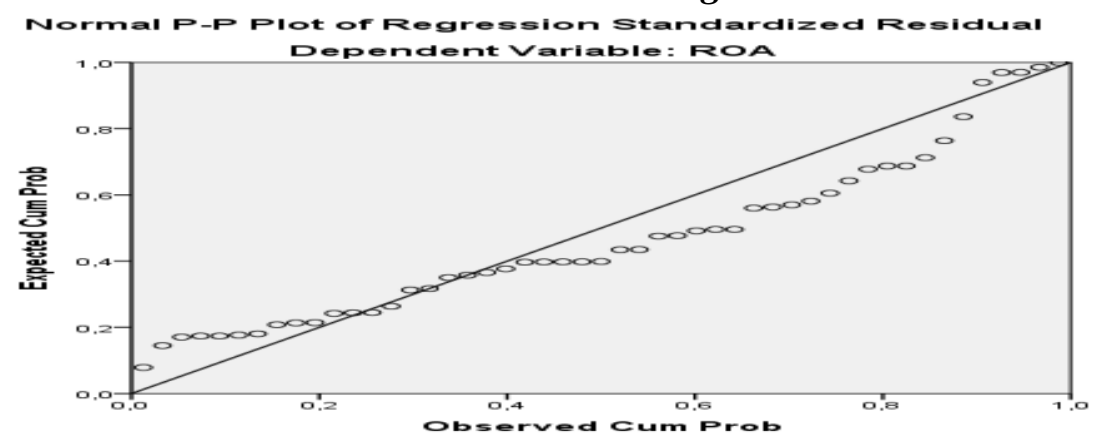

Sumber: Olahan Tahun 2021

\section{Metode One Sample Kolmogorov-Smirnov Test}

Uji ini melihat nilai signifikansi residual, jika signifikansi lebih besar atau sama dengan 0,05 , maka residual terdistribusi secara normal.

Tabel 1. One-Sample Kolmogorov-Smirnov Test

\begin{tabular}{llr}
\hline & One-Sample Kolmogorov-Smirnov Test & Unstandardized Residual \\
\hline $\mathrm{N}$ & & 49 \\
Normal Parameters ${ }^{\text {a,b }}$ & Mean & $0 \mathrm{E}-7$ \\
& Std. Deviation &, 71091212 \\
Most Extreme Differences & Absolute &, 157 \\
& Positive &, 157 \\
& Negative &,- 122 \\
Kolmogorov-Smirnov Z & & 1,102 \\
Asymp. Sig. (2-tailed) & &, 176 \\
a. Test distribution is Normal. & &, \\
\hline
\end{tabular}




\section{Uji Multikolinearitas}

Metode pengujiannya adalah dengan melihat nilai Invlation Factor (VIF) dan Tolerance pada model regresi. Apabila nilai VIF $<10$ dan nilai Tolerance $>0,1$ maka tidak terdapat multikolinearitas dalam model regresi yang dibangun.

\begin{tabular}{|c|c|c|c|}
\hline \multicolumn{4}{|c|}{ Coefficients $^{a}$} \\
\hline \multirow{2}{*}{\multicolumn{2}{|c|}{ Model }} & \multicolumn{2}{|c|}{ Collinearity Statistics } \\
\hline & & Tolerance & VIF \\
\hline \multicolumn{4}{|c|}{ 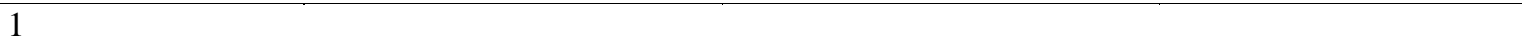 } \\
\hline & $\mathrm{BOPO}$ & ,456 & 2,195 \\
\hline & NPL & ,455 & 2,199 \\
\hline & LDR & ,994 & 1,006 \\
\hline a. & ble: ROA & & \\
\hline
\end{tabular}

Sumber: Olahan Tahun 2021

Dari hasil uji diatas yang diperlihatkan melalui tabel Coefficients, diketahui bahwa nilai VIF dari ketiga variabel kurang dari 10 dan nilai Tolerance lebih besar dari 0,1 maka dapat disimpulkan bahwa model regresi yang dibangun tidak terdapat gejela multikolinearitas.

\section{Uji Autokorelasi}

Autokorelasi menjelaskan adanya korelasi antara residual pada periode $\mathrm{t}$ dengan residual pada periode sebelumnya ( $\mathrm{t}-1)$ dalam model regresi yang dibangun. Model regresi yang baik adalah yang tidak terdapat autokorelasi. Metode pengujian menggunakan uji Durbin-Waston (DW Test). Singgih Santoso (2000) dalam Sunyoto (2012:179) memaparkan ukuran untuk menentukan ada tidaknya data mengalami autokorelasi sebagai berikut:

Tabel 3. Batas Pengujian nilai Durbin-Watson

\begin{tabular}{|c|c|}
\hline D-W & Kriteria \\
\hline Kurang dari -2 & Ada autokorelasi positif \\
\hline Antara -2 s/d +2 & Tidak ada autokorelasi \\
\hline Diatas +2 & Ada autokorelasi negatif \\
\hline
\end{tabular}

Tabel 4. Model Summary

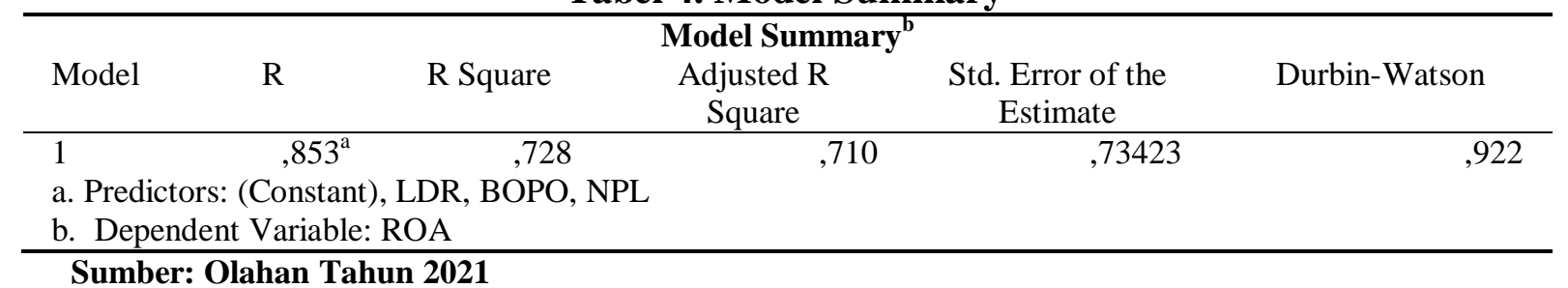

Sumber: Olahan Tahun 2021

Dalam Model Summary angka Durbin-Waston sebesar 0,922 berarti berada diantara -2 s/d +2 sehingga tidak terjadi gejala autokorelasi antar data penelitian sesuai batas pengujian nilai Durbin-Waston.

\section{Uji Heteroskedastisitas}

Model regresi yang tidak terjadi heteroskedastisitas adalah model yang baik. Salah satu pengujian yang dapat digunakan untuk melihat ada tidaknya heteroskedastisitas adalah dengan Scatter Plot (nilai prediksi ZPRED dengan residual SRESID). Jika titik-titik menyebar dengan pola yang tidak teratur diatas dan dibawah angka nol pada sumbu Y, maka tidak terjadi heteroskedastisitas 


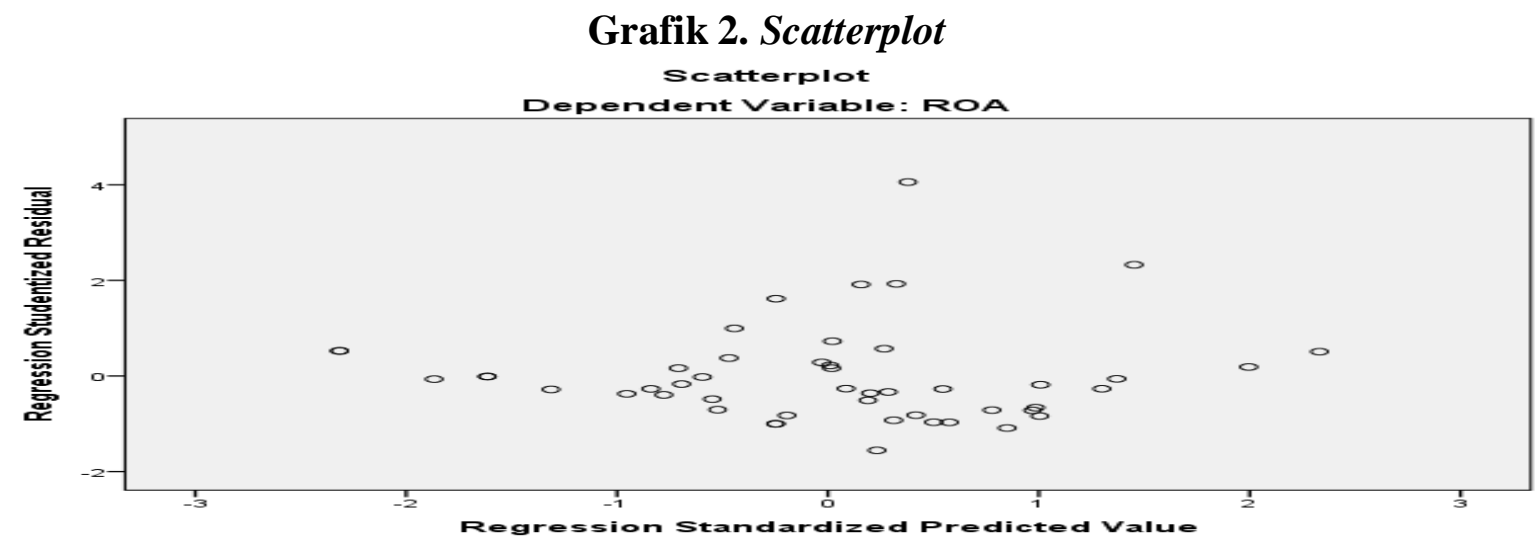

Berdasarkan gambar diatas memperlihatkan titik-titik yang menyebar dengan pola yang tidak beraturan dibawah dan diatas angka nol pada sumbu Y. Sehingga dapat disimpulkan bahwa dalam model regresi yang dibangun tidak terjadi masalah heteroskedastisitas.

\section{Analisis Deskriptif}

Hasil analisis deskriptif dari variabel-variabel penelitian yaitu BOPO (X1), NPL (X2), LDR (X3) dan ROA (Y) dapat dilihat pada tabel di bawah ini :

Tabel 5. Analisis Deskripsi

\begin{tabular}{lrrrrr}
\hline & \multicolumn{5}{c}{ Descriptive Statistics } \\
& $\mathrm{N}$ & \multicolumn{1}{c}{ Minimum } & Maximum & \multicolumn{1}{c}{ Mean } & \multicolumn{1}{c}{ Std. Deviation } \\
\hline BOPO & 49 & 50,49 & 92,73 & 72,6720 & 8,50452 \\
NPL & 49 &, 99 & 4,50 & 2,3659 & 1,03382 \\
LDR & 49 & 63,02 & 122,79 & 86,0963 & 13,96734 \\
ROA & 49 & 1,41 & 7,07 & 3,7482 & 1,36390 \\
Valid N (listwise) & 49 & & & & \\
\hline
\end{tabular}

Sumber: Olahan Tahun 2021

\section{Analisis Inferensial}

\section{Regresi Linear Sederhana}

1. Pengaruh Variabel BOPO (X1) Terhadap Variabel ROA (Y) PT Bank Pembangunan Daerah Nusa Tenggara Timur

Berikut adalah hasil perhitungan dengan bantuan SPSS 20 for windows:

Tabel 6. Coefficients Variabel BOPO terhadap Variabel ROA

\begin{tabular}{|c|c|c|c|c|c|}
\hline \multirow{3}{*}{ Model } & & Coeffici & \multirow{3}{*}{$\begin{array}{c}\text { Standardized } \\
\text { Coefficients } \\
\text { Beta }\end{array}$} & \multirow{3}{*}{$\mathrm{t}$} & \multirow{3}{*}{ Sig. } \\
\hline & \multicolumn{2}{|c|}{ Unstandardized Coefficients } & & & \\
\hline & B & Std. Error & & & \\
\hline 1 (Constant) & 13,419 & ,955 & & 14,051 & , 000 \\
\hline BOPO &,- 133 & 013 &,- 830 & $-10,194$ & ,000 \\
\hline a. Dependent & ROA & & & & \\
\hline
\end{tabular}

Sumber: Olahan Tahun 2021

Dari hasil diatas didapat persamaan:

$\operatorname{ROA}(Y)=13,419-0,133$ BOPO $\left(X_{1}\right)$

Nilai $t_{\text {hitung }}$ yang didapat sebesar 10,194 ini menggunakan nilai absolute dari $t_{\text {hitung }}$ yaitu hanya menggunakan angkanya saja sedangkan simbol negatif diabaikan dan ini berlaku untuk uji 1 sisi (one tailed). Dengan demikian nilai $t_{\text {hitung }}$ lebih besar dari pada nilai $t_{\text {tabel }}$ $(10,194>1,678)$ dan juga diperolah nilai signifikansi yang lebih kecil dari alpha $(0,000<$ $0,05)$. Maka $\mathrm{H}_{1}$ diterima yang menerangkan bahwa variabel BOPO (X1) berpengaruh negatif 
dan signifikan terhadap variabel ROA (Y) PT Bank Pembangunan Daerah Nusa Tenggara Timur.

2. Pengaruh Variabel NPL (X2) Terhadap Variabel ROA (Y) PT Bank Pembangunan Daerah Nusa Tenggara Timur.

Tabel 7. Coefficients Variabel NPL terhadap Variabel ROA

\begin{tabular}{|c|c|c|c|c|}
\hline \multicolumn{5}{|c|}{ Coefficients $^{\mathrm{a}}$} \\
\hline \multirow[t]{2}{*}{ Model } & Unstandardized Coefficients & \multirow{2}{*}{$\begin{array}{l}\text { Standardized Coefficients } \\
\text { Beta }\end{array}$} & \multirow[t]{2}{*}{$\mathrm{t}$} & \multirow[t]{2}{*}{ Sig. } \\
\hline & B $\quad$ Std. Error & & & \\
\hline \multirow{2}{*}{$\begin{array}{ll}1 & \text { (Constant) } \\
& \text { NPL }\end{array}$} & 6,072 & & 18,334 & ,000 \\
\hline &,- 982 &,- 744 & $-7,644$ & 000 \\
\hline \multicolumn{5}{|c|}{ a. Dependent Variable: ROA } \\
\hline
\end{tabular}

\section{Sumber: Olahan Tahun 2021}

Dari hasil diatas didapat persamaan regresinya:

$\operatorname{ROA}(Y)=6,072-0,982 \operatorname{NPL}\left(X_{2}\right)$

Nilai $t_{\text {hitung }}$ yang didapat sebesar 7,644 194 ini menggunakan nilai absolute dari $t_{\text {hitung }}$ yaitu hanya menggunakan angkanya saja sedangkan simbol negatif diabaikan dan ini berlaku untuk uji 1 sisi (one tailed). Dengan demikian nilai $t_{\text {hitung }}$ lebih besar dari pada nilai $t_{\text {tabel }}$ $(7,644>1,678)$, dan juga diperoleh nilai signifikansi yang lebih kecil dari alpha $(0,000<$ 0,05). Maka $\mathrm{H}_{2}$ diterima yang menerangkan bahwa variabel NPL $\left(\mathrm{X}_{2}\right)$ berpengaruh negatif dan signifikan terhadap variabel ROA (Y) PT Bank Pembangunan Daerah Nusa Tenggara Timur.

3. Pengaruh Variabel LDR (X3) Terhadap Variabel ROA (Y) PT Bank Pembangunan Daerah Nusa Tenggara Timur.

Tabel 8. Coefficients Variabel LDR terhadap Variabel ROA

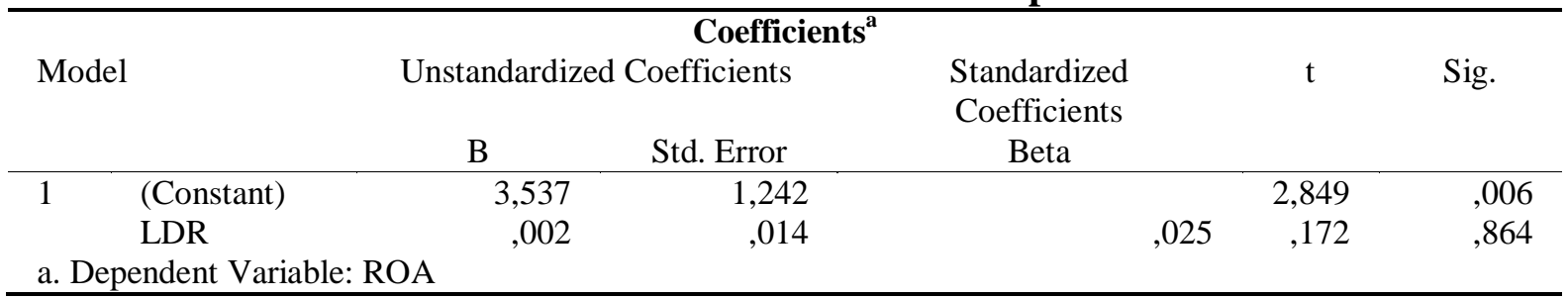

Sumber: Olahan Tahun 2021

Dari hasil diatas didapat persamaan regresinya:

$\operatorname{ROA}(Y)=3,537+0,002 \operatorname{LDR}\left(X_{3}\right)$

Nilai $t_{\text {hitung }}$ yang didapat sebesar 0,172 ; dengan demikian nilai $t_{\text {hitung }}$ lebih kecil dari pada nilai $t_{\text {tabel }}(0,172<1,678)$, dan juga diperoleh nilai signifikansi yang lebih besar dari alpha $(0,864>0,05)$. Hasil dalam penelitian ini menunjukan bahwa variabel LDR $\left(\mathrm{X}_{3}\right)$ tidak berpengaruh signifikan terhadap ROA (Y) Bank NTT. Maka $\mathrm{H}_{3}$ ditolak yang menerangkan bahwa variabel LDR $\left(\mathrm{X}_{3}\right)$ berpengaruh positif dan signifikan terhadap variabel ROA (Y) PT Bank Pembangunan Daerah Nusa Tenggara Timur.

\section{Analisis Regresi Linear Berganda}

Analisis regresi linear berganda merupakan salah satu alat analisis yang digunakan untuk mencari tahu pengaruh dua atau lebih variabel independen terhdapa satu variabel dependen. Hasil olah data dengan bantuan SPSS 20 For Windows sebagai berikut: 
Tabel 9. Coefficients Variabel BOPO, NPL dan LDR terhadap Variabel ROA

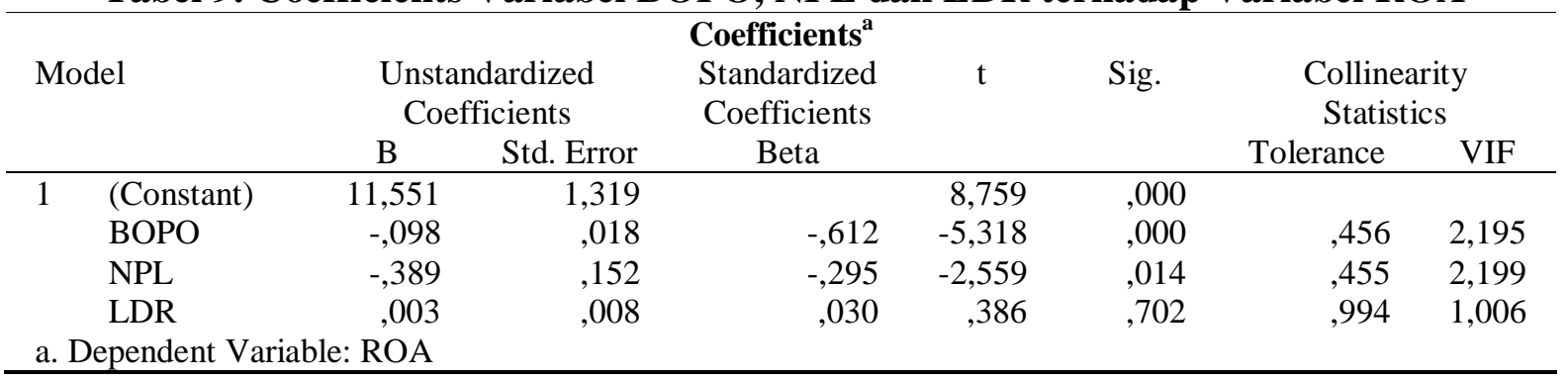

Sumber: Olahan Tahun 2021

Persamaan regresi linier berganda didapat sebagai berikut:

ROA $(Y)=11,551-0,098$ BOPO $\left(X_{1}\right)-0,389$ NPL $\left(X_{2}\right)+0,003 \operatorname{LDR}\left(X_{3}\right)$

Persamaan diatas menjelaskan:

Nilai konstanta $\left(\beta_{0}\right)$ adalah 11,551 ; artinya jika variabel BOPO (X1), variabel NPL (X2) dan variabel LDR (X3) nilainya adalah 0, maka nilai ROA (Y) adalah sebesar 11,551.

\section{Koefisien Determinasi}

Santoso (2001) dalam Priyatno (2011:251) menyatakan bahwa jika regresi dengan lebih dari dua variabel bebas atau independen digunakan Ajusted $R 2$ sebagai koefisien determinasi. Nilai Ajusted $R 2$ diperoleh sebesar sebesar 0,710 atau sebesar $71 \%$. Hal ini menjelaskan bahwa presentasi sumbangan pengaruh variabel independen yaitu BOPO, NPL, dan LDR terhadap variabel ROA sebesar $71 \%$. Sedangkan sisanya sebesar $29 \%$ dipengaruhi oleh variabel lain yang tidak dimasukan dalam model penelitian ini.

Tabel 10. Model Summary

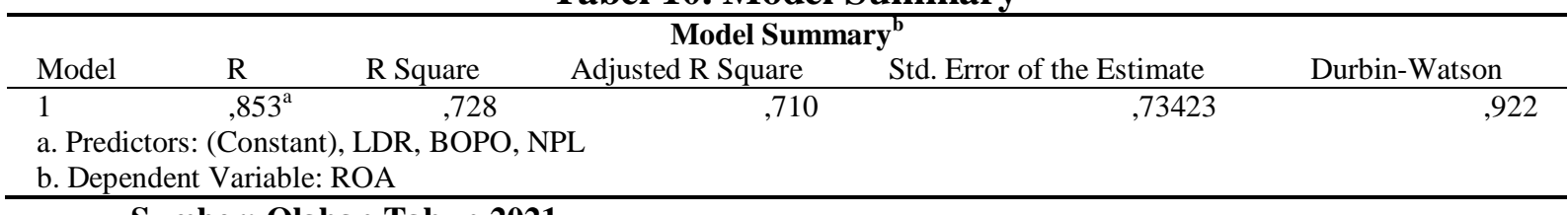

\section{Uji F}

\section{Sumber: Olahan Tahun 2021}

Priyatno (2011:258) menyatakan, "uji F digunakan untuk menguji pengaruh variabel bebas secara bersama-sama berpengaruh terhadap variabel tergantung". Dari hasil uji $\mathrm{F}$ diperoleh nilai F-hitung > F-tabel $(40,211>2,816)$ dan berdasarkan signifikansi pada uji $\mathrm{F}$ kurang dari $0,05(0,000<0,05)$, maka $\mathrm{H}_{4}$ diterima yang menerangkan bahwa variabel BOPO $\left(\mathrm{X}_{1}\right)$, NPL $\left(\mathrm{X}_{2}\right)$ dan LDR $\left(\mathrm{X}_{3}\right)$ secara simultan berpengaruh terhadap ROA (Y) PT Bank Pembangunan Daerah Nusa Tenggara Timur.

Tabel 11. ANOVA

\begin{tabular}{|c|c|c|c|c|c|c|}
\hline \multicolumn{7}{|c|}{ ANOVA $^{a}$} \\
\hline \multicolumn{2}{|l|}{ Model } & Sum of Squares & Df & Mean Square & $\mathrm{F}$ & Sig. \\
\hline \multirow[t]{3}{*}{1} & Regression & 65,031 & 3 & 21,677 & 40,211 &, $000^{\mathrm{b}}$ \\
\hline & Residual & 24,259 & 45 &, 539 & & \\
\hline & Total & 89,290 & 48 & & & \\
\hline \multicolumn{7}{|c|}{ a. Dependent Variable: ROA } \\
\hline \multicolumn{7}{|c|}{ b. Predictors: (Constant), LDR, BOPO, NPL } \\
\hline
\end{tabular}

Sumber: Olahan Tahun 2021

Pengaruh Biaya Operasional Per Pendapatan Operasional (BOPO) $\left(\mathbf{X}_{1}\right)$ Terhadap Return On Asset (ROA) (Y) PT Bank Pembangunan Daerah Nusa Tenggara Timur

Biaya operasional per pendapatan operasional (BOPO) merupakan rasio untuk mengukur tingkat efisiensi bank dalam memanfaatkan seluruh potensi atau kekayaan yang 
ada. Jika biaya operasional lebih besar daripada pendapatan operasional yang diperoleh maka rasio BOPO akan meningkat yang menandakan kurang efisiennya bank dalam melakukan aktivitas operasional. Hal ini menyebabkan menurunnya laba yang diperoleh sehingga ROA bank semakin kecil.

Hasil penelitian ini tidak sejalan dengan penelitian sebelumnya yang dilakukan Lemiyana \& Litriani (2016) yang menunjukan BOPO berpengaruh negatif dan tidak signifikan terhadap ROA, namun hasil penelitian ini konsisten dengan hasil penelitian sebelumnya yang dialakukan Putra (2013), Dewi, Herawati, \& Sulindawati (2015), Dewi A. S (2017), Fajari \& Sunarto (2017), Maria (2015), Peling \& Sedana (2018), Wibisono \& Wahyuni (2017), Yolanda ( 2019) yang menyatakan variabel BOPO berpengaruh negatif dan signifikan terhadap ROA bank.

\section{Pengaruh Non Performing Loan (NPL) $\left(\mathrm{X}_{2}\right)$ Terhadap Return On Asset (ROA) (Y) PT Bank Pembangunan Daerah Nusa Tenggara Timur.}

NPL yang semakin tinggi menjelaskan banyaknya jumlah kredit bermasalah yang dialami bank. Banyaknya kredit bermasalah atau yang tidak dapat ditagih ataupun macet akan berdampak pada penurunan pendapatan operasional bank dan tentunya berdampak pada laba yang diperoleh akan semakin kecil.

Hasil penelitian ini tidak sejalan dengan penelitian sebelumnya yang dilakukan oleh Lemiyana \& Litriani (2016) yang menunjukan bahwa NPL berpengaruh positif dan signifikan terhadap ROA, hasil penelitian yang dilakukan oleh Putra (2013) yang menunjukan bahwa NPL berpengaruh positif dan tidak signifikan terhadap ROA dan hasil penelitian yang dilakukan oleh Maria (2015) dan Yolanda (2019) yang menunjukkan bahwa NPL berpengaruh negatif dan tidak signifikan terhadap ROA. Namun penelitian ini konsisten dengan hasil penelitian sebelumnya yang dilakukan oleh Dewi, Herawati, \& Sulindawati (2015), Dewi A. S (2017) dan Peling \& Sedana (2018) yang menyatakan bahwa variabel NPL berpengaruh negatif dan signifikan terhadap variabel ROA.

\section{Pengaruh Loan To Deposit Ratio (LDR) (X $\mathrm{X}_{3}$ ) Terhadap Return On Asset (ROA) (Y) PT Bank Pembangunan Daerah Nusa Tenggara Timur}

Loan to Deposit Ratio (LDR) disebut juga rasio kredit terhadap total dana pihak ketiga yang digunakan untuk mengukur dana pihak ketiga yang disalurkan dalam bentuk kredit. Semakin tinggi nilai rasio LDR menunjukan semakin rendahnya kemampuan likuiditas bank yang bersangkutan sehingga kemungkinan suatu bank dalam kondisi bermasalah akan semakin besar, sebaliknya semakin rendah rasio LDR menunjukan kurangnya efektifitas bank dalam menyalurkan kredit sehingga hilangnya kesempatan bank untuk memperoleh laba. Jika rasio berada pada standar yang ditetapkan bank Indonesia, maka laba akan meningkat (dengan asumsi bank menyalurkan kreditnya dengan efektif).

Hasil penelitian ini menyatakan bahwa LDR tidak berpengaruh signifikan terhadap ROA. Mengingat adanya sumbangan efektif (SE) terbesar yaitu dari BOPO sebesar 50,8\% terhadap ROA yang menyebabkan tingginya biaya operasional yang harus ditanggung oleh bank NTT, sehingga walaupun dana yang diterima oleh bank cukup tinggi, namun bank juga harus mempergunakan dana tersebut untuk membiayai kegiatan operasionalnya yang menyebabkan turunnya kemampuan bank dalam menghasilkan laba.

Hasil penelitian ini tidak sejalan dengan penelitian sebelumnya yang dilakukan Dewi, Herawati, \& Sulindawati (2015), Peling \& Sedana (2018) dan Putra (2013) yang menunjukkan bahwa LDR berpengaruh positif dan signifikan terhadap ROA, hasil penelitian yang dilakukan oleh Maria (2015) yang menunjukkan bahwa NPL berpengaruh positif dan tidak signifikan terhadap ROA dan hasil penelitian yang dilakukan oleh Yolanda (2019) yang 
menunjukkan bahwa LDR berpengaruh negatif dan tidak signifikan terhadap ROA. Namun penelitian ini konsisten dengan hasil penelitian sebelumnya yang diteliti oleh Lemiyana \& Litriani ( 2016), Dewi, Sinarwati, \& Darmawan (2014) dan Setyowati \& Budiwinarto (2017) yang menunjukkan bahwa NPL tidak ada pengaruh terhadap ROA.

Pengaruh Biaya Operasional per Pendapatan Operasional (BOPO), Non Performing Loan (NPL) dan Loan to Deposit Ratio (LDR) Secara Simultan Terhadap Return On Asset (ROA) PT Bank Pembangunan Daerah Nusa Tenggara Timur

Biaya operasional yang semakin besar tentunya akan mengurangi pendapatan operasional dan sekalipun pendapatan operasional yang diperoleh sama dengan biaya operasional; pihak bank akan tetap mengalami kerugian. Hal ini akan berdampak pada laba yang semakin menurun dan berdampak juga pada rasio ROA. Jika ROA semakin kecil maka pemanfaatan asset akan semakin sulit disebabkan dana yang tidak cukup.

Salah satu pendapatan terbesar bank ialah melalui kredit, maka besar kecilnya nilai ROA juga ditentukan oleh besar kecilnya kredit. Kelancaran kredit dapat dilihat dari rasio NPL, ketika NPL semakin meningkat yang berarti meningkatnya kredit bermasalah yang tidak dapat ditagih, akan berdampak pada menurunnya pendapatan operasional yang juga akan sangat berpengaruh pada penurunan ROA Bank NTT.

Loan to Deposit Ratio merupakan rasio yang digunakan untuk menunjukan kemampuan bank menarik dana simpanan masyarakat atau dana pihak ketiga dengan dana yang dikeluarkan dalam bentuk kredit. Semakin tinggi rasio LDR menunjukan semakin rendahnya kemampuan likuiditas Bank NTT sehingga kemungkinan bank dalam kondisi bermasalah. Sebaliknya semakin rendah rasio LDR menunjukan kurangnya efektifitasnya bank dalam menyalurkan kredit sehingga hilangnya kesempatan bank untuk memperoleh laba. Jika rasio berada pada standar yang ditetapkan bank Indonesia, maka laba akan meningkat (dengan asumsi bank tersebut menyalurkan kreditnya dengan efektif).

Dari hasil penelitian ini, BOPO, NPL dan LDR sangat mempengaruhi fluktuasi dari ROA bank. BOPO, NPL dan LDR merupakan variabel internal dari Bank NTT, semakin tinggi variabel BOPO dan NPL ini maka ROA bank akan semakin menurun. Sedangkan variabel LDR, jika rasio ini berada pada standar yang ditetapkan bank Indonesia maka laba akan meningkat (dengan asumsi bank tersebut menyalurkan kreditnya dengan efektif). Ketiga variabel ini harus diperhatikan dengan baik yang dibutuhkan regulasi dan strategi yang tepat untuk mengatasi kenaikan pada ketiga variabel ini. Jika tidak diperhatikan maka asset produktif tidak dapat memberi nilai tambah dan jangka waktu penggunaan asset tetap semakin pendek yang disebabkan laba yang diperoleh semakin kecil yang tidak dapat memenuhi dan membiayai asset yang dimiliki.

\section{SIMPULAN}

Berdasarkan hasil penelitian dan pembahasan, maka dapat ditarik bebarapa kesimpulan:

1) Biaya Operasional per Pendapatan Operasional $\left(X_{1}\right)$ berpengaruh negatif dan signifikan terhadap Return On Asset (Y) pada PT Bank Pembangunan Daerah Nusa Tenggara Timur. Hal ini dibuktikan dengan koefisien regresi yang bernilai negatif sebesar - 0,133 dan juga nilai t hitung yang lebih besar dari nilai t tabel $(10,194>1,678)$ dengan tingkat signifikansi $0,000<0,05$.

2) Non Performing Loan $\left(\mathrm{X}_{2}\right)$ berpengaruh negatif dan signifikan terhadap Return On Asset (Y) pada PT Bank Pembangunan Daerah Nusa Tenggara Timur. Hal ini dibuktikan dari koefisien regresi yang bernilai negatif sebesar $-0,982$ dan juga nilai $t$ hitung yang lebih besar dari nilai t tabel $(7,644>1,678)$ dengan tingkat signifikansi $0,000<0,05$. 
3) Loan to Deposit Ratio $\left(\mathrm{X}_{3}\right)$ tidak berpengaruh signifikan terhadap Return On Asset (Y) pada PT Bank Pembangunan Daerah Nusa Tenggara Timur. Hal ini dibuktikan dari koefisien regresi sebesar 0,002 dan juga nilai t hitung yang lebih kecil dari nilai t tabel $(0,172<1,678)$ dengan tingkat signifkansi $0,864>0,05$.

4) Biaya Operasional per Pendapatan Operasional $\left(\mathrm{X}_{1}\right)$, Non Performing Loan $\left(\mathrm{X}_{2}\right)$ dan Loan to Deposit Ratio $\left(\mathrm{X}_{3}\right)$ secara simultan berpengaruh terhadap Return On Asset (Y) PT Bank Pembangunan Daerah Nusa Tenggara Timur. Hal ini dibuktikan dari nilai $F$ hitung lebih besar dari nilai $\mathrm{F}$ tabel $(40,211>2,816)$ dengan tingkat signifikansi $0,000<0,05$.

\section{SARAN}

Berdasarkan hasil penelitian dan rumusan kesimpulan diatas, sebagai tindak lanjut dari hasil penelitian maka peneliti merumuskan beberapa rekomendasi atau saran diantaranya sebagai berikut:

1) Dari hasil penelitian diketahui bahwa BOPO berpengaruh negatif dan signifikan $(-0,133)$ terhadap ROA. Berdasarkan hasil yang diperoleh maka hendaknya Bank NTT lebih mengefisienkan lagi penggunaan biaya operasional bersamaan dengan meningkatkan pendapatan operasional.

2) Dari hasil penelitian diketahui bahwa NPL berpengaruh negatif dan signifkan $(-0,982)$ terhadap ROA. Berdasarkan hasil yang diperoleh maka Bank NTT perlu mengambil kebijakan agar profitabilitas dapat ditingkatkan dengan menerapkan manajemen resiko secara konsisten dan konsekuen agar bisa menekan tingginya tingkat Non Performing Loan (NPL), dengan lebih memperhatikan penyaluran kredit kepada nasabah, memantau secara benar di lapangan tentang penggunaan kredit, melakukan pengecekan tentang kondisi sebenarnya calon nasabah di lapangan dan memperhitungkan cash flow dari kredit yang disalurkan.

3) Dari hasil penelitian diketahui bahwa LDR tidak berpengaruh signifikan $(0,002)$ terhadap ROA. Berdasarkan hasil yang diperoleh maka Bank NTT perlu menekan tingginya biaya operasional yang ditanggung oleh bank. Karena tingginya biaya operasional yang ditanggung oleh bank, maka walaupun dana yang diterima oleh bank cukup tinggi, namun bank juga harus mempergunakan dana tersebut untuk membiayai kegiatan operasionalnya yang menyebabkan turunnya kemampuan Bank NTT dalam menghasilkan laba.

4) Dari hasil penelitian diketahui bahwa BOPO, NPL dan LDR secara simultan berpengaruh terhadap ROA. Berdasarkan hasil yang diperoleh maka Bank NTT harus memperhatikan ketiga variabel ini dengan baik yang dibutuhkan regulasi dan strategi yang tepat untuk mengatasi kenaikan pada ketiga variabel ini. Jika tidak diperhatikan maka asset produktif tidak dapat memberi nilai tambah dan jangka waktu penggunaan asset tetap semakin pendek yang disebabkan laba yang diperoleh semakin kecil yang tidak dapat memenuhi dan membiayai asset yang dimiliki.

\section{DAFTAR PUSTAKA}

Bank NTT. Laporan Tahunan Bank NTT tahun 2014-2019. http://www.bpdntt.co.id/template/front/archive/Laporan_Tahunan.(Diakses Tanggal 5 Desember 2020).

Dewi, A. S. (2017). Pengaruh CAR, BOPO, NPL, NIM, dan LDR terhadap ROA pada Perusahaan di Sektor Perbankan yang Terdaftar di BEI periode 2012-2016. Jurnal Pundi , 1 (3), 223-236.(Diakses Tanggal 20 Maret 2021).

Dewi, K. A., Sinarwati, N. K., \& Darmawan, N. A. (2014). Pengaruh Capital Adequacy Ratio (CAR), Loan to Deposit Ratio (LDR), dan Perbandingan Biaya Operasional dengan Pendapatan Operasional (BOPO) terhadap Return On Assets (ROA) pada Bank 
Umum yang Terdaftar di Bursa Efek Indonesia Tahun 2008-2012. e-Journal S1 Ak , 2 (1).(Diakses Tanggal 20 Maret 2021).

Dewi, L. E., Herawati, N. T., \& Sulindawati, L. G. (2015). Analisis Pengaruh NIM, BOPO, LDR, dan NPL terhadap Profitabilitas (Studi Kasus pada Bank Umum Swasta Nasional yang Terdaftar pada Bursa Efek Indonesia Periode 2009-2013). e-Journal S1 Ak. Universitas Pendidikan Ganesha , 3 (1).(Diakses Tanggal 25 Mei 2021).

Fajari, S., \& Sunarto. (2017). Pengaruh CAR, LDR, NPL, BOPO terhadap Profitabilitas Bank (Studi Kasus Perusahaan Perbankan yang Tercatat di Bursa Efek Indonesia Periode Tahun 2011 sampai 2015). 853-862.(Diakses Tanggal 25 Mei 2021).

Halimah, S. N., \& Komariah, E. (2017). Pengaruh ROA, CAR, NPL, LDR, BOPO terhadap Nilai Perusahaan Bank Umum. Jurnal Akuntansi, Ekonomi dan Manajemen Bisnis , 5 (1), 14-25.(Diakses Tanggal 25 Mei 2021).

Lemiyana, \& Litriani, E. (2016). Pengaruh NPF, FDR, BOPO terhadap Return On Asset (ROA) pada Bank Umum Syariah. I-Economic , 2 (1), 31-49.(Diakses Tanggal 25 Mei 2021).

Maria, A. (2015). Pengaruh CAR, BOPO, NIM, NPL, dan LDR terhadap ROA: Studi Kasus Pada 10 Bank Terbaik Di Indonesia Periode 2007-2011. Jurnal Ilmiah Mahasiswa Universitas Surabaya , 4 (1), 1-19.(Diakses Tanggal 25 Mei 2021).

Putra, A. F. (2013). Pengaruh LDR, IPR, APB, NPL, IRR, PDN, BOPO, FBIR dan FACR terhadap Return On Asset (ROA) pada Bank Pembangunan Daerah di Indonesia. 118.(Diakses Tanggal 25 Mei 2021).

Setyowati, L., \& Budiwinarto, K. (2017). Analisis Pengaruh NIM, BOPO, LDR, NPL, CAR terhadap ROA pada Bank Umum Nasional di Bursa Efek Indonesia Periode 20122015. Ekonomi Bisnis Dan Kewirausahaan , VI (2), 140-158.(Diakses Tanggal 25 Mei 2021).

Sohilauw, M. I. (2016). Analisis Pengaruh CAR, NPL, BOPO, NIM dan LDR terhadap ROA PT. Bank Sulselbar Periode 2001-2010. Jurnal Ecosystem , 16 (1), 1-23.(Diakses Tanggal 25 Mei 2021).

Tanor, M. O., Sabijono, H., \& Walandouw, S. K. (2015). Analisis Laporan Keuangan Dalam Mengukur Kinerja Keuangan Pada PT.Bank Artha Graha Internasional,tbk. Jurnal EMBA , 3 (3), 639-649.(Diakses Tanggal 29 Mei 2021).

Wibisono, M. Y., \& Wahyuni, S. (2017). Pengaruh CAR, NPF, BOPO, FDR terhadap ROA yang dimediasi oleh NOM. Jurnal Bisnis \& Manajemen , 17 (1), 41-62.(Diakses Tanggal 25 Mei 2021).

Yolanda, L.S. (2019).Pengaruh Faktor Internal dan Makroekonomi Terhadap Profitabilitas Bank BUMN (Periode 2009-2015).Procuratio: Jurnal Ilmiah Manajemen, 7(1), 4054. (Diakses Tanggal 29 Mei 2021). 